\title{
Nutrient Intake, Digestibility and Growth Performance of Local Sheep in Western Tigray, Ethiopia
}

\author{
Mulugeta Ftiwi \\ Lecturer at Raya University, Ethiopia \\ Gebrehiwot Tadess \\ Lecturer at Mekelle university, Ethiopia
}

\begin{abstract}
Twenty-five yearling intact male sheep with an average live weight of $19 \pm 1.7 \mathrm{~kg}$ (mean \pm Standard deviation) were used in the experiment. The study was to investigate the effect of feeding different levels of sesame seed cake supplementation on feed intake, live weight gain and carcass parameters of sheep fed wheat bran and teff straw, as well as to evaluate the appropriate economic levels to get optimum profit in feedlot growing rams. The experimental design was a complete randomized block design (CRBD) with five treatments and five replications. The treatment diets, namely, 0, 150, 200, 250 and 300g Dry matter (DM)/head/day sesame seed cake were assigned randomly to the sheep with a basal diet. There was significantly higher $(\mathrm{P}<0.05)$ total Dry matter intake (DMI) in the sesame supplemented group than the control treatment. Similarly, there was a significant difference $(\mathrm{P}<0.05)$ among all treatments in total Crude protein intake $(\mathrm{CPI})$ due to the increased level of supplementation. Digestibility of Crude protein (CP), Dry matter (DM) and Organic matter (OM) were also significantly higher $(\mathrm{P}<0.05)$ for sheep supplemented with the different level of SSC (sesame seed cake) than the control treatment. Though daily live weight gain was significantly higher $(\mathrm{P}<0.05)$ for sesame supplemented treatment as compared to control, a positive average daily body weight gain was observed in all treatment groups. The feed conversion efficiency was significantly $(\mathrm{P}<0.05)$ higher for the sesame supplement as compared to control. There was a significant difference $(\mathrm{P}<0.05)$ in the final body weight between the sesame supplemented group and the control. The mean values of slaughter weight, empty body weight and rib-eye area were significantly $(\mathrm{P}<0.05)$ higher for supplemented treatments than the control. The highest hot carcass weight was recorded with the highest level (300g SSC) supplemented sheep. Considering the economic return (Marginal rate of return), the highest level sesame seed cake supplemented sheep could be recommended as the optimum level for feedlot growing. Generally the present study indicated that supplementation of sheep with different levels of SSC had an effect on feed intake, digestibility, and carcass parameters, and the effects were relatively more pronounced on sheep supplemented with the highest level of sesame seed cake. The partial budget analysis also indicated that the highest level of sesame seed cake supplemented sheep had returned a higher profit margin than the other levels of supplementation. Therefore, supplementation with $300 \mathrm{~g}$ Dry matter (DM)/head/day sesame seed cake is biologically more efficient and economically more profitable and thus could be recommended.
\end{abstract}

Keywords: Body weight gain, digestibility, carcass parameters and growing lambs

DOI: $10.7176 / \mathrm{JBAH} / 9-1-06$

\section{Introduction}

Developing countries have nearly two third of the world's livestock population. However, they produce less than one third of world's meat and one fifth of its milk (ILRI/FAO, 1995). Ethiopia, one of the developing countries in Sub-Saharan Africa, is known for its huge livestock population, but meat and milk production are very low. A total of 800,000 tons of milk and 220,000 tons of meat are produced annually, which accounts $30 \%$ for the agricultural products that contribute $46 \%$ of the Gross Domestic Product (GDP) (Azage and Alemu, 1998).

Ethiopia's per capita milk consumption is estimated to be about $19.2 \mathrm{~kg} /$ person/year, which is very low as compared to average per capita consumption of Africa, $37.2 \mathrm{~kg} /$ person/year (FAO, 2001). Among several factors, feed shortage both in terms of quantity and quality is a major problem hindering the development of livestock industry in Ethiopia. In the highlands of Ethiopia, the feed requirement to maintain the livestock population is estimated to be 55 million tones of dry matter (DM), which is much larger than the 40 million tones of DM estimated to be produced annually. This indicates an annual livestock feed deficit of about $22 \%$. The factors contributing to the deficit in DM supply are fast deterioration of the natural grazing land associated with a rise in crop cultivation, over stocking /over grazing and recurrent droughts. This situation requires seeking better ways for utilization of alternative livestock feed resources from agricultural and industrial by-products that are relatively cheaper sources for supplementation of animals on fibrous basal feeds. Nowadays, small-scale mechanical oil extraction and grain-milling industries are expanding in different parts of the country. These byproducts provide potential sources of supplements in animal feeding. In Northwestern Zone of Tigray, farmers and small scale merchants practice oil extraction traditionally from sesame seed using draft power, thus enabling sesame seed cake to be available at cheaper price throughout the year and is the major protein source in the area. 
Wheat bran is also produced in large quantities by a flourmill in the town and at $60 \mathrm{~km}$ distance from the study area and thus readily available in the market. Even though these agro-industrial by-products are available in region, these products are currently not effectively utilized by smallholder farmers for feeding to animals, mainly due to lack of information on supplementary value and experience about their potential as supplements to small ruminants is inadequate. Nevertheless, the use of these by-products is a potential alternative through which the productivity of animals can be improved. However, information on the nutrition of tropical sheep is scanty and there is no information on the optimum ratio of the by-products for various physiological conditions of sheep. In addition, there is no information in the use of these by-products for feeding the local sheep in the area. The objective of this study was therefore conducted to determine feed intake, digestibility, body weight (BW) change and carcass parameters in koraro sheep type fed teff (Eragrostis tef) straw and supplemented with graded levels of concentrate consisting of $(150 \mathrm{gWB}, 150 \mathrm{gSSC}),(150 \mathrm{gWB}, 200 \mathrm{gSSC}),(150 \mathrm{gWB}, 250 \mathrm{gSSC}),(150 \mathrm{gWB}$, $300 \mathrm{gSSC}$ ), on dry matter (DM) basis, respectively.

\section{Materials and Methods \\ Experimental Feed Preparation and Feeding Management}

The supplement feeds, sesame seed cake and wheat bran, used for the experiment were purchased from different sesame oil extractors (camel is the only animal used for oil extraction in shire and the surroundings) and Omona wheat flour milling factory, in shire respectively, and the basal diet (teff straw) was purchased locally from farmers. They were stored in a clean feed storing house which was inconvenient for microbial growth. The supplement feeds were thoroughly mixed at the given proportion after proper grinding of the sesame seed cake. Except the control animals, those in the other treatments were supplemented with the respective level of sesame seed cake at 0800 and 1600 hours in two equal portions for 90 days. The animals had ad libitum access to water and common salt licks. Daily offer and refusal of the basal feed and the supplements were recorded for each animal. Representative samples were taken for the feed offer every morning before feeding. Supplement and basal feed offers and refusals were weighed for each animal daily and their differences were recorded as a daily feed intake per animal. Feed conversion ratio was calculated by dividing the daily total DM intake by the daily live weight gain. The feed conversion efficiency was calculated by dividing the daily live weight gain by daily DM intake and multiplied by 100.

\section{Experimental Animals}

Twenty-five yearling growing intact sheep weighed $19.1 \pm 1.17 \mathrm{~kg}$ (mean \pm Standard deviation) were purchased from Koraro local market (Embadanso) based on their dentition and information from the owners. The animals were drenched with a broad spectrum anthelmentic (Albendazol) drug against internal parasites and sprayed (Accaricide / Ectoparasite) against external parasites. They were vaccinated against common diseases (anthrax and pasteurelosis) during the quarantine period. Then the experimental animals were individual penned $(1.2 * 1.0 \mathrm{~m} / \mathrm{head})$ and offered tef straw with supplement of $0,150,200,250,300 \mathrm{DM} \mathrm{g} /$ day sesame oil cake for $\mathrm{T} 1, \mathrm{~T} 2, \mathrm{~T} 3, \mathrm{~T} 4, \mathrm{~T} 5$ respectively for 21 days to get them adapted to the feeds prior to the beginning of the experiment. Animals were closely observed for the occurrence of any ill health and disorders during the experimental period.

Experimental Design and Dietary Treatments

The experiment was conducted using a randomized complete block design (RCBD) with five treatments and five replications. The experimental sheep were blocked based on their initial weight into five blocks of five animals each. A mean of two consecutive live weights were taken after over night fasting to determine initial weight of animals Treatment diets were randomly assigned to each animal in the treatment in such a way that each animal had equal chance of receiving one of the treatment diets. The experimental animals were supplied tef straw, Tap water, and salt blocks comprising sodium chloride ad libitum daily in individual pens. The different levels of SSC for T1, T2, T3, T4, and T5 were $0 \mathrm{~g}, 150 \mathrm{~g}, 200 \mathrm{~g}, 250 \mathrm{~g}$, and 300g head/day on DM bases, respectively. The different levels of SSC were formulated according to the growth requirements of the sheep as recommendations by the NRC (1981) and by considering their body weight and the expected weight gain. The experiment was conducted for 90 day of feeding trial and 7 days of digestibility trial. The five treatments were randomly assigned to each animal in a blocking giving five animal per treatment. The treatments used in the experiment were as follows:

Feed intake

For each animal, daily offered and refusal of each treatment diet was measured and recorded throughout the experiment for 90 days. Daily supplement and teff straw offers and refusals were weighed and recorded for each animal and the difference between the daily offer and refusal were calculated to arrive at the daily feed intake of each experimental sheep. Samples of feeds offered were collected on batches of feeds that of refusal were collected for each animal and pooled for each treatment.

Body weight changes

Initial body weight of the experimental animals was taken at the beginning of the study during morning hours 
after overnight fasting. All animals were weighed during morning hours after overnight fasting using suspended weighing scale (Salter model) with sensitivity of 100 grams. The weights were recorded for each yearling growing rams against its identification number on a weight register book every ten-day interval and the activity was continued through out the experiment. Daily body weight gain was calculated as the difference between final live weight and initial live weight divided by the number of days.

Digestibility trial

The digestibility trial was conducted after twenty-one days of adaptation period to the feed and new environment. It was comprised of three days period for animal to adapt to carry of the fecal collection bags followed by sevenday feces collection period. Feces were collected and weighed every morning for each animal before giving of feed or water. The daily collected feces from each animal was separately mixed thoroughly and $10 \%$ was sampled and kept in air tight plastic containers and stored at $-20{ }^{\circ} \mathrm{C}$ up to the completion of the digestibility trial. In addition, amount of feed offered and refusals were collected, weighed and recorded every morning. At the end, the fecal sampled of each sheep was taken and partially dried at $60{ }^{\circ} \mathrm{C}$ for 72 hours and then samples were ground and stored in air tight container (glass). Such samples were taken to Mekele University nutrition laboratory using ice box containers for analysis. The apparent digestibility coefficient (DC) of dry matter (DM), organic matter $(\mathrm{OM})$ crude protein $(\mathrm{CP})$, crude fiber $(\mathrm{CF})$, acid detergent fiber (ADF) and acid detergent lignin (ADL) was calculated using the following equation: (Mc Donald et al., 2002)

Nutrient digestibility coefficient $(\%)=$ nutrient intake- nutrient excreted in feces $\times 100$

Chemical Analysis

\section{Nutrient intake}

Representative samples of daily feed offers, refusals and feces were ground to pass through a $1 \mathrm{~mm}$ sieve screen size. The ground samples were analyzed for contents of dry matter (DM), Ash, crude fiber (CF) and Nitrogen using the procedure of AOAC (1990). Acid detergent fiber (ADF) and acid detergent lignin (ADL) were analyzed following the procedure of Van Soest et al., (1991).

The crude protein (CP) was computed as $\mathrm{N} \times 6.25$.

Data Analysis

The analyses of variance (ANOVA) on the experimental data were run using JMP5. The treatment means of the parameters were separated using Tukey HSD (Tukey Honestly Significant Difference) Test. The model used for the analysis of all parameters feed intake, weight gain, digestibility, and carcass parameters of the experiment was:

$$
Y_{i j}=\mu+\alpha_{i}+\beta_{j}+\varepsilon_{i j}
$$

Where: $Y_{i j}=$ response variable (feed intake, body weight gained, digestibility,

$$
\begin{aligned}
\mu & =\text { overall mean } \\
\alpha_{\mathrm{i}} & =\mathrm{i}^{\text {th }} \text { treatment effect (feeds) } \\
\beta_{\mathrm{j}} & =\text { block effect (five-blocks) } \\
\varepsilon_{\mathrm{ij}} & =\mathrm{i}^{\text {th }} \text { random error (undefined factors) }
\end{aligned}
$$

\section{RESULTS AND DISCUSSION}

Chemical composition of the experimental feeds

Based on the resulted indicated in (table, 2) the DM. OM, ASH, CP, CF, ADF and ADL content of teff straw offered was $88.6 \%, 94.6 \%, 5.4 \%, 2.67 \%, 37.8 \%, 45.5 \%$, and $37.9 \%$ respectively. The DM and OM was almost similar to the content reported by Zemicheal (2007) having the values of $88.14 \%, 94.75$ respectively. The CP content of tef straw in this experiment was $2.67 \%$ which falls in the range of values of $2.5-7.5 \% \mathrm{CP}$ content for tef straw reported by Seyoum and Zinash (1998). But, it is below the CP content reported by Zemicheal (2007) having the values of $3.06 \%$. This difference might be due to season, post harvesting management and level and type fertilization.

Table 2. Chemical composition of the teff straw, WB and SSC

\begin{tabular}{|l|lllllllll|}
\hline & \multicolumn{3}{|c}{ Concentrate } & Tef & \multicolumn{5}{c|}{ Tef straw Refusal } \\
Nutrients & WB & SSC & mixture & straw offer & T1 & T2 & T3 & T4 & T5 \\
\hline DM (\%) & 87.02 & 88.73 & 87.08 & 88.6 & 91.5 & 90.3 & 89.6 & 89.1 & 88.9 \\
Ash (\%DM) & 3.95 & 9.4 & 6.03 & 5.4 & 5.20 & 5.00 & 5.20 & 5.30 & 5.20 \\
OM (\%DM) & 96.05 & 90.6 & 91.97 & 94.6 & 94.8 & 95.0 & 94.8 & 94.7 & 94.8 \\
CP (\%DM) & 16.87 & 39.92 & 24.56 & 2.67 & 2.13 & 2.07 & 1.96 & 2.16 & 2.27 \\
CF (\%DM) & 47.68 & 16.24 & 29.38 & 37.8 & 39.9 & 38.2 & 39.5 & 38.7 & 39.1 \\
ADF (\%DM) & 13.98 & 10.4 & 10.24 & 45.5 & 45.8 & 46.0 & 46.3 & 46.4 & 46.7 \\
ADL (\%DM) & 4.23 & 8.35 & 3.21 & 37.9 & 38.6 & 39.8 & 38.7 & 38.1 & 39.7 \\
\hline
\end{tabular}

$\mathrm{DM}=$ Dry matter; $\mathrm{OM}=$ Organic matter; $\mathrm{CP}=$ Crude protein; $\mathrm{CF}=$ Crude fiber; 
$\mathrm{ADF}=$ Acid detergent fiber; $\mathrm{ADL}=$ Acid detergent lignin; tef straw; $\mathrm{WB}=$ Wheat bran .

$\mathrm{SSC}=$ sesame seed cake

In this study, the ADF and ADL contents of teff straw were 45.5 and 37.9, respectively which was higher than the $44.5 \%$ and $5.32 \%$ reported by Seyoum and Zinash (1998). The CF part of the straw was 37.8 and this was similar to the result of reported by Beyene et al.(1977). The CP contents of the concentrate feed ingredients, namely, wheat bran and sesame seed cake were $16.87 \%$ and $39.92 \%$ respectively. The CP content of wheat bran in this study was comparable to the values of $16.5 \%, 16.41 \%, 16.82 \%$ reported by Solomon (2004); Awet (2007); and Tesfay (2007) respectively, but lowers than the values $17.19 \%$, and $19.99 \%$ reported by Getnet et al. (1999) and Alemu (1981), respectively. The variation might be due to the effect of processing in milling industries and the quality of the original grain used in the milling industries.

The CP content of the sesame seed cake was 39.92\%, which was higher than the CP contents of $30.93 \%$ reported by Solomon (1992); 38\% by Ensminger (2002) and 37.5\% by Njie (1995). This may be due to the difference in efficiency on method of extraction with in the screw pressing and similar suggestions were also reported in other studies (Solomon, 1992; Ensminger, 2002; Njie, 1995). The straw refusals contained lower CP and higher $\mathrm{CF}, \mathrm{ADF}$, and $\mathrm{ADL}$ than the teff straw offer in all treatments, indicating the selective behavior of sheep on portion of feeds with better nutritive value. The ADF content (10.24) of sesame seed cake and wheat bran (13.98) was almost similar to the result reported by Zemicheal (2007) 10.38 and 13.08. The ADF and ADL of wheat bran contents were higher than to other reports (Genet, 1998; Simert, 2005; Solomon, 2001 and Tesfaye et al., 2001). This may be due to the differences in milling efficiency of the factory and varietal difference of wheat grain. Generally, the contrasting nature of nutrients, namely high CP and low cell wall fiber contents in the supplements, and low CP and high cell wall fiber contents in the teff straw justifies the use of the supplements in teff straw based feeding of sheep.

\section{Feed and Nutrient Intake}

The mean daily DM intake of teff straw, total DMI and total nutrients intake with different level of sesame seed cake supplementation is presented in Table 3. the DM and OM intake of teff straw in sheep fed From the result no significant difference $(\mathrm{p}>0.05)$ was observed on the DM and OM intake of teff straw among treatment, even though DM and OM intake of teff straw increased as the level of supplementation decreased. Bonsi et al. (1996) reported that supplementation improved the intakes of total DM and OM. Sheep in the control consumed more DM and OM of teff straw as compared to the supplemented treatments. This might be due to the relatively low $\mathrm{CP}$ and high CF content of the feeds used in the control group. In this control group, sheep were seeking to meet their nutrient requirement only through the intake of relatively more teff straw DM than the other treatments. This also indicated that there was a substitution effect of supplement at the expense of intake of tef straw. As the level of supplementation increased, there was a depression of teff straw DM and OM intake. The increased TDMI with increased levels of supplement in the diets also agrees with the findings of Akinsoyinu (1975), and Crabtree and Williams (1971). Consistent with the present result, supplementation trial on Gwamble goat of Zambia at $0,50,100$, and $150 \mathrm{~g}$ peanut cake per animal per day showed that an increase in the level of peanut cake in concentrate mixture, increased total dry matter intake (Njwe and Olubajo, 1989). Besides, the DMI and growth rate in Alpine and Nubian goats increased linearly as the level of protein concentration in the diet increased. The TCP intake among the different treatment groups was significantly different $(\mathrm{p}<0.05)$. There was an increasing trend of CP intake as the level of supplementation increases, the highest being in T5 and the lowest in T1. The TCP intake for the different treatments was 33.56, 79.22, 85.41, 87.89 and 92.44g/day for T1, T2, T3, T4 and T5 respectively. The increased CP intake with the sesame seed cake supplementation level might be due to the increased total DMI and higher CP content of the sesame seed cake than the basal diet. The CP intake of the experiment was comparable with the value reported by Tesfay (2007) on Afar rams fed on teff straw basal diet supplemented with concentrate mixtures, but lower than the CP intake reported by Bonsi et al. (1996) on sheep with teff straw basal diet supplemented with cotton seed cake. 
Table 3: Daily feed intake of sheep fed on basal diet of teff straw and supplemented with different levels of sesame seed cake in Tahtay koraro woreda

\begin{tabular}{|c|c|c|c|c|c|c|c|}
\hline Parameters & T1 & $\mathrm{T} 2$ & T3 & T4 & T5 & SL & SEM \\
\hline DMI (teff straw, g/day) & $393.3^{\mathrm{a}}$ & $386.4^{\mathrm{a}}$ & $380.0^{\mathrm{a}}$ & $358.4^{\mathrm{a}}$ & $357.0^{\mathrm{a}}$ & ns & 27.072 \\
\hline DMI (Supplement, g/day) & $150.2^{\mathrm{d}}$ & $267.72^{\mathrm{c}}$ & $292.18^{\mathrm{c}}$ & $340.22^{\mathrm{b}}$ & $382.88^{\mathrm{a}}$ & $*$ & 7.223 \\
\hline TDMI(g/day) & $543.5^{\mathrm{c}}$ & $654.12^{\mathrm{abc}}$ & $672.18^{b c}$ & $698.62^{\mathrm{ab}}$ & $739.88^{\mathrm{a}}$ & $*$ & 13.796 \\
\hline OMI teff straw(g/day) & $368.48^{\mathrm{a}}$ & $362.02^{\mathrm{a}}$ & $347.62^{\mathrm{a}}$ & $335.8^{\mathrm{a}}$ & $333.7^{\mathrm{a}}$ & ns & 25.366 \\
\hline OMI Supplement(g/day) & $144.93^{\mathrm{d}}$ & $246.22^{\mathrm{c}}$ & $268.72^{c}$ & $312.9^{\mathrm{b}}$ & $352.14^{\mathrm{a}}$ & $*$ & 6.643 \\
\hline Total OMI(g/day) & $513.41^{\mathrm{b}}$ & $608.24^{\mathrm{ab}}$ & $615.82^{\mathrm{ab}}$ & $648.7^{\mathrm{a}}$ & $685.84^{\mathrm{a}}$ & $* *$ & 12.401 \\
\hline CPI teff straw(g/day) & $8.26^{\mathrm{a}}$ & $8.11^{\mathrm{a}}$ & $7.79^{\mathrm{a}}$ & $7.53^{\mathrm{a}}$ & $7.75^{\mathrm{a}}$ & ns & 0.569 \\
\hline CPI Supplement(g/day) & $25.3^{\mathrm{d}}$ & $71.11^{\mathrm{c}}$ & $77.62^{\mathrm{c}}$ & $80.36^{\mathrm{b}}$ & $84.69^{\mathrm{a}}$ & $* *$ & 1.915 \\
\hline Total CPI(g/day) & $33.56^{\mathrm{d}}$ & $79.22^{\mathrm{c}}$ & $85.41^{\mathrm{c}}$ & $87.89^{\mathrm{b}}$ & $92.44^{\mathrm{a}}$ & $* *$ & 0.936 \\
\hline CFI teff straw(g/day) & $148.65^{\mathrm{a}}$ & $146.04^{\mathrm{a}}$ & $140.24^{\mathrm{a}}$ & $135.47^{\mathrm{a}}$ & $139.46^{\mathrm{a}}$ & ns & 10.234 \\
\hline CFI supplement(g/day) & $71.61^{\mathrm{d}}$ & $78.66^{\mathrm{cd}}$ & $85.85^{\mathrm{c}}$ & $99.93^{\mathrm{b}}$ & $112.49^{\mathrm{a}}$ & $* *$ & 2.121 \\
\hline Total CFI(g/day) & $220.26^{\mathrm{a}}$ & $224.66^{\mathrm{a}}$ & $226.09^{\mathrm{a}}$ & $235.4^{\mathrm{a}}$ & $251.95^{\mathrm{a}}$ & ns & 4.995 \\
\hline ADFI teff straw(g/day) & $167.14^{\mathrm{a}}$ & $164.22^{\mathrm{a}}$ & $157.54^{\mathrm{a}}$ & $152.33^{\mathrm{a}}$ & $156.81^{\mathrm{a}}$ & $\mathrm{ns}$ & 11.512 \\
\hline ADFI supplement(g/day) & $21.0^{\mathrm{d}}$ & $27.42^{\mathrm{c}}$ & $29.92^{\mathrm{c}}$ & $34.84^{\mathrm{b}}$ & $39.21^{\mathrm{a}}$ & $* *$ & 0.74 \\
\hline Total ADFI(g/day) & $188.14^{\mathrm{a}}$ & $191.64^{\mathrm{a}}$ & $187.44^{\mathrm{a}}$ & $187.13^{\mathrm{a}}$ & $196.02^{\mathrm{a}}$ & $\mathrm{ns}$ & 5.629 \\
\hline ADLI teff straw(g/day) & $149.04^{\mathrm{a}}$ & $146.43^{\mathrm{a}}$ & $140.62^{\mathrm{a}}$ & $135.83^{\mathrm{a}}$ & $139.84^{\mathrm{a}}$ & ns & 10.262 \\
\hline ADLI supplement(g/day) & $6.35^{\mathrm{d}}$ & $8.59^{c}$ & $9.38^{\mathrm{c}}$ & $10.92^{\mathrm{b}}$ & $12.37^{\mathrm{a}}$ & $* *$ & 0.233 \\
\hline Total ADLI(g/day) & $155.35^{\mathrm{a}}$ & $155.02^{\mathrm{a}}$ & $150.0^{\mathrm{a}}$ & $146.75^{\mathrm{a}}$ & $152.21^{\mathrm{a}}$ & ns & 5.107 \\
\hline
\end{tabular}

a, b, c,abc,be d = means within a row not bearing a common superscript letter significantly differ, ns = not

significant; $\mathrm{DMI}=$ dry matter intake; $\mathrm{SEM}=$ standard error of mean; $\mathrm{OMI}=$ organic matter intake; $\mathrm{CPI}=$ crude protein intake; $\mathrm{CF}=$ crude fiber; $\mathrm{ADF}=$ acid detergent fiber; $\mathrm{ADL}=$ acid detergent lignin; $\mathrm{SL}=$ significant level.

The average daily $\mathrm{CP}$ requirement for maintenance of sheep weighing $30 \mathrm{Kg}$ was stated to be $36 \mathrm{~g} \mathrm{CP}$ (Ranjhan, 1997). This suggests that the supplemented sheep in the study had crude protein intake more than their maintenance requirement. As a result there was no loss in body weight of the animal at the end of the experiment; rather all animals in the control group were seen to increase in their body weight. From this finding, teff straw with wheat bran might keep crude protein of equal to or more than their maintenance requirement of the experimental animals.

The intake of CF $(220.26,224.66,226.09,235.4,251.95)$ and ADF $(188.14,191.64,187.44,187.13,196.02)$ were not significantly $(\mathrm{p}>0.05)$ affected due to supplementation. Similar results were reported by Asnakew (2005) and Tesfay (2007) for Hararghe highland goats supplemented with concentrate and fed hay basal diet, and Afar rams supplemented with concentrate mixture and fed teff straw basal diet, respectively.

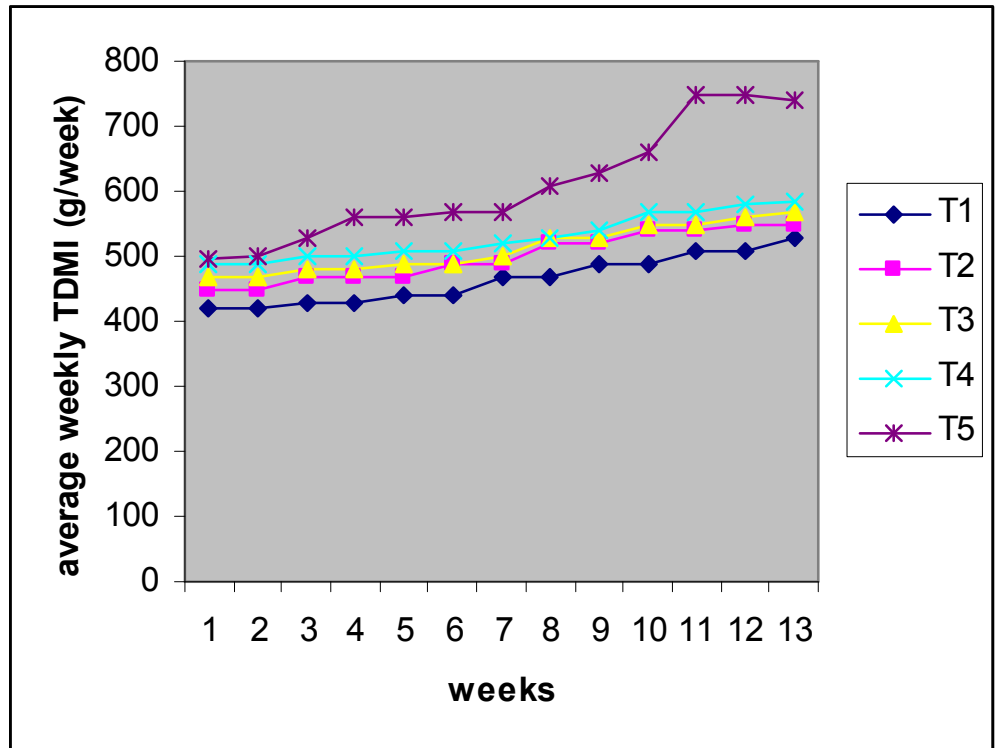

Figure 1: Trends in total dry matter intake of sheep fed on basal diet of teff straw and supplemented with different levels of sesame seed cake in Tahtay koraro woreda. 


\section{Digestibility Trial}

Chemical Composition of Feces

There was a significantly lower $(\mathrm{p}<0.05)$ crude protein content in the feces of the control group as compared to the different of level sesame seed cake supplemented groups (Table 4). Even though there was numerically an increased trend of crude protein content as the level of sesame seed cake increased, there was no significant difference $(p>0.05)$ in the feces of the other treatments, (i.e. T2, T3, T4 and T5). This could be due to high crude protein intake of the supplemented treatments and might be inappropriate utilization of dietary crude protein with increased level of supplementation. On the other hand the nutrients in the feces of the experimental animals indicated that there was no significant difference $(\mathrm{p}>0.05)$ on DM, OM, CF, ADF and ADL contents among all treatments. But, generally the control group had numerically higher contents of the above parameters (i.e. T1 $>$ T2 $>$ T3 $>$ T4 $>$ T5). The reason might be due to more consumption of teff straw, which contained relatively high fiber (less digestible) and also due to deficiency in crude protein that leads to excretion of more nutrients in the form of feces.

Table 4: Chemical composition of feces in sheep fed on teff straw and supplemented With different levels of sesame seed cake.

\begin{tabular}{|llllllll|}
\hline Parameters & T1 & T2 & T3 & T4 & T5 & SL & SEM \\
\hline DM (g/day) & $141.3^{\mathrm{a}}$ & $128.9^{\mathrm{a}}$ & $124.8^{\mathrm{a}}$ & $119.18^{\mathrm{a}}$ & $113.36^{\mathrm{a}}$ & $\mathrm{ns}$ & 10.59 \\
OM (g/day) & $137.21^{\mathrm{a}}$ & $117.77^{\mathrm{a}}$ & $114.4^{\mathrm{a}}$ & $110.12^{\mathrm{a}}$ & $97.73^{\mathrm{a}}$ & $\mathrm{ns}$ & 11.34 \\
CP (g/day) & $12.16^{\mathrm{b}}$ & $13.26^{\mathrm{a}}$ & $14.3^{\mathrm{a}}$ & $14.81^{\mathrm{a}}$ & $15.83^{\mathrm{a}}$ & $* *$ & 0.518 \\
CF (g/day) & $86.13^{\mathrm{a}}$ & $82.02^{\mathrm{a}}$ & $77.46^{\mathrm{a}}$ & $75.29^{\mathrm{a}}$ & $74.93^{\mathrm{a}}$ & $\mathrm{ns}$ & 6.97 \\
ADF (g/day) & $121.65^{\mathrm{a}}$ & $116.74^{\mathrm{a}}$ & $111.15^{\mathrm{a}}$ & $103.2^{\mathrm{a}}$ & $101.78^{\mathrm{a}}$ & $\mathrm{ns}$ & 5.60 \\
ADL (g/day) & $111.03^{\mathrm{a}}$ & $101.6^{\mathrm{a}}$ & $93.06^{\mathrm{ab}}$ & $91.5^{\mathrm{a}}$ & $90.1^{\mathrm{a}}$ & $\mathrm{ns}$ & 5.616 \\
\hline
\end{tabular}

a, b, ab, means the same row with different superscripts differ significantly, ns= not significant;

$\mathrm{SEM}=$ standard error of mean; $\mathrm{SL}=$ significant level; $\mathrm{DM}=$ dry matter; $\mathrm{OM}=$ organic matter;

$\mathrm{CP}=$ crude protein $\mathrm{CF}=$ crude fiber; $\mathrm{ADF}=$ acid detergent fiber; $\mathrm{T} 1=$ treatment one,

(control); T2 = $150 \mathrm{~g} \mathrm{SSc}$; $3=200 \mathrm{~g} \mathrm{SSc} ; \mathrm{T} 4=250 \mathrm{~g} \mathrm{SSc} ; 300 \mathrm{~g} \mathrm{SSc}$

Nutrient Digestibility

There was a significant difference in $\mathrm{DM}, \mathrm{OM}$ and $\mathrm{CP}(\mathrm{p}<0.05)$ digestibility between supplemented and control groups (Table 5). Apparent digestibility of $\mathrm{CP}$ and $\mathrm{OM}$ of the supplemented groups were significantly increased $(\mathrm{p}<0.05)$ due to supplementation. But, there, was no significant difference $(\mathrm{p}>0.05)$ in DM, OM, and CP digestibility among the supplemented treatments. Similarly there was no significant difference in the digestibility of DM among T1, T2, T3, and T4 even though there was trend of numerically increased DM apparent digestibility as the level of supplementation increased. This might be due to concentrate supplementation has improved the apparent digestibility of DM. Inline with this result Khanal et al. (1999) reported that there was an increment in apparent DM digestibility for oil cake supplementations.

There was no significant difference $(\mathrm{p}>0.05)$ in the apparent digestibility of CP among the supplemented treatments, but apparent digestibility of $\mathrm{CP}$ was increased due to the high total $\mathrm{CP}$ intake of the supplemented animals. Preston et al., 1984, reported that any increase in protein intake may lead to an increase in the apparent digestibility of crude protein especially if, the intake is marginally sufficient in protein. In this study supplementation did not significantly ( $p>0.05)$ affect the CF, ADF and ADL apparent digestibility. This is also in agreement with MacRae and Armstrong (1969), who reported supplementation, had little or no effect on the digestibility of $\mathrm{CF}, \mathrm{ADF}$ and ADF.

Table 5: Apparent Nutrient Digestibility in sheep fed on teff straw based diet and Supplemented with different levels of SSC in Tahtay koraro woreda.

\begin{tabular}{|llllllll|}
\hline Nutrients & T1 & T2 & T3 & T4 & T5 & SL & SEM \\
\hline DM (\%) & $55.37^{\mathrm{b}}$ & $64.74^{\mathrm{ab}}$ & $64.99^{\mathrm{ab}}$ & $61.0^{\mathrm{ab}}$ & $70.32^{\mathrm{a}}$ & $* *$ & 3.183 \\
OM (\%) & $53.05^{\mathrm{b}}$ & $67.0^{\mathrm{a}}$ & $66.79^{\mathrm{a}}$ & $67.23^{\mathrm{a}}$ & $73.24^{\mathrm{a}}$ & $* *$ & 3.145 \\
CP (\%) & $68.71^{\mathrm{b}}$ & $91.57^{\mathrm{a}}$ & $89.57^{\mathrm{a}}$ & $90.06^{\mathrm{a}}$ & $92.6^{\mathrm{a}}$ & $* *$ & 1.887 \\
CF (\%) & $67.08^{\mathrm{a}}$ & $69.18^{\mathrm{a}}$ & $69.3^{\mathrm{a}}$ & $66.58^{\mathrm{a}}$ & $75.34^{\mathrm{a}}$ & $\mathrm{ns}$ & 3.856 \\
ADF (\%) & $44.54^{\mathrm{a}}$ & $37.42^{\mathrm{a}}$ & $48.67^{\mathrm{a}}$ & $42.72^{\mathrm{a}}$ & $50.57^{\mathrm{a}}$ & ns & 4.868 \\
ADL (\%) & $38.27^{\mathrm{a}}$ & $31.36^{\mathrm{a}}$ & $44.54^{\mathrm{a}}$ & $32.88^{\mathrm{a}}$ & $42.59^{\mathrm{a}}$ & ns & 4.897 \\
\hline
\end{tabular}

${ }^{\mathrm{a}, \mathrm{b}}=$ means within a row not bearing a common superscript letter differ significantly; $\mathrm{ns}=$

not significant; $\mathrm{SEM}=$ standard error of mean; $\mathrm{SL}=$ significant level; $\mathrm{DM}=$ dry matter;

$\mathrm{OM}=$ organic matter; $\mathrm{CP}=$ crude protein; $\mathrm{CF}=$ crude fiber; $\mathrm{ADF}=$ acid detergent fiber;

$\mathrm{T} 1=$ (control); T2 =150 g SSc; T3 = $200 \mathrm{~g} \mathrm{SSc} ; \mathrm{T} 4=250 \mathrm{~g} \mathrm{SSc}$;5=300 g SSc.

The lower DM, OM, and CP digestibility resulted for T1 as compared to the supplemented treatments (T2, T3, T4, and T5) could be due to the relatively lower crude protein and higher crude fiber contents of the teff straw (basal diet). This can affect the microbial growth and fermentation in the rumen of sheep (Bonsi et al., 
1995). As a result fiber degradation was lower in the control treatment group, while the opposite could have been true for the supplemented treatments (Ibrahim et al., 1989). The lack of significant difference in DM digestibility among T1, T2, T3 and T4 and in $\mathrm{CF}, \mathrm{ADF}$ and ADL digestibility among the control and the supplemented treatments might be due to a change in the microbial population in the rumen. At this supplementation level, the protein supplements may depress the rumen $\mathrm{P}^{\mathrm{H}}$ and therefore, the cellulolytic microbes favor the proteolytic and amylolytic populations.

Feed Utilization

The control treatment had significantly higher $(\mathrm{p}<0.05)$ feed conversion ratio than the supplemented treatments and lower $(\mathrm{p}<0.05)$ feed conversion efficiency as compared to the highest level sesame seed cake supplemented group (T5). But there was no significant $(\mathrm{p}>0.05)$ difference in their FCE among the other treatments even though, there was an increasing trend as the level of supplementation increased (i.e. T1 $<\mathrm{T} 2<\mathrm{T} 3<\mathrm{T} 4$ ), Table 6 .

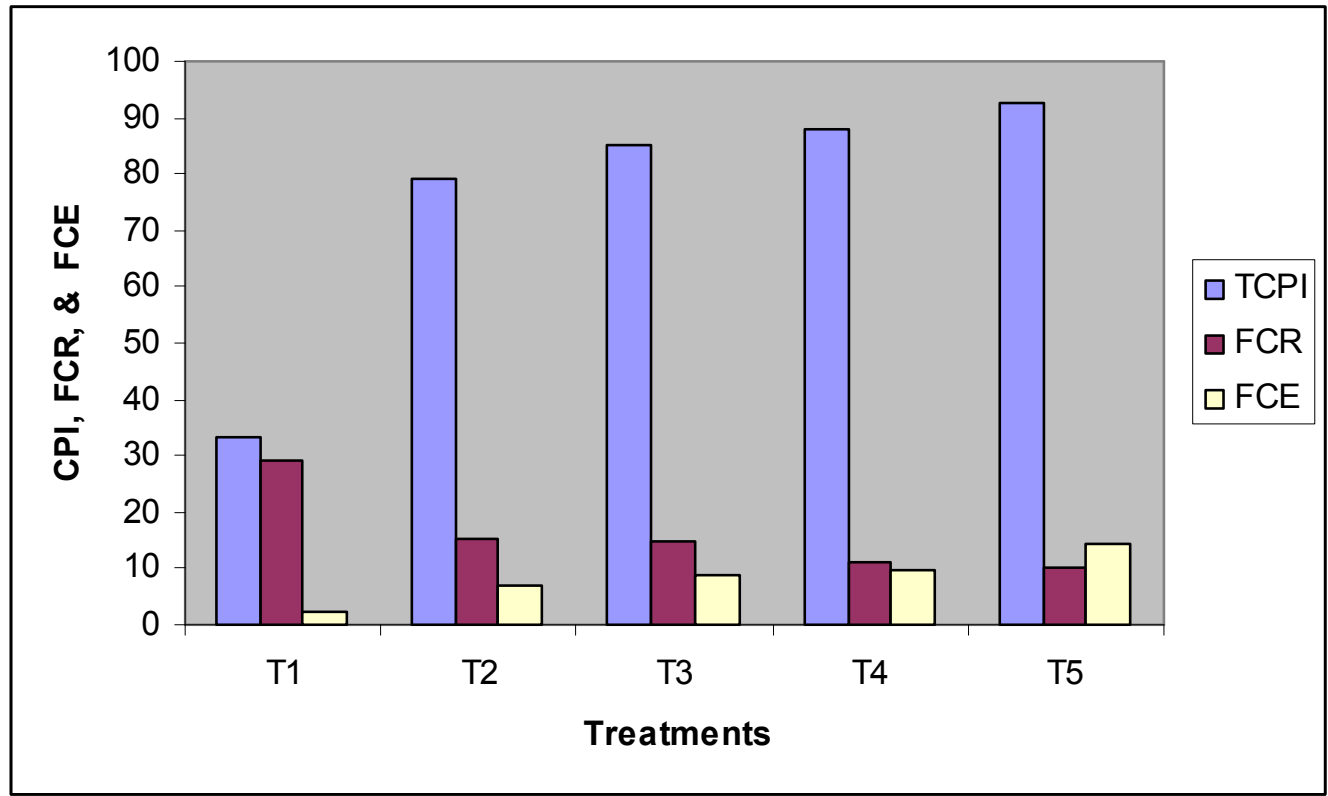

Figure 2: Feed conversion efficiency and ratio of sheep fed teff straw based diet and supplemented with SSC in Tahtay koraro woreda

The improved feed conversion efficiency seems to be related to higher nutrient concentration of the supplement and the consequent increase in live weight gain. Although, there was not significance $(p>0.05)$ difference in their feed conversion efficiency among the treatments, the highest level of sesame seed cake supplementation has resulted in significantly $(p<0.05)$ higher feed conversion efficiency as compared to the control treatment and other supplemented group. This indicates that rams in T5 were efficient in the utilization of nutrients for their live weight gain. Similarly, Abule (1994) reported that there was a linear increment of feed utilization efficiency with the level of supplementation.

\section{Body Weight Change}

Heavier $(\mathrm{p}<0.05)$ average daily body weight was gained in sheep supplemented with highest level (T5) of sesame seed cake group than the other supplemented groups and the control treatment (Table 6). At the same time the T2, T3, and T4 sesame seed cake supplemented group had significantly $(p<0.05)$ higher average daily weight gain than the control group. However, there was no significant $(p>0.05)$ difference among the supplemented groups (T2, T3 and T4) and between T4 and T5 even though, the weight gain was numerically higher in the order of $\mathrm{T} 4>\mathrm{T} 3>\mathrm{T} 2$ and $\mathrm{T} 5>\mathrm{T} 4$ for both cases.

The control group had the lowest body weight change, which is attributed to the inclusion of wheat bran that supplied nutrients almost beyond the limit for their maintenance requirement. Similar reports are given by Trach (2004) for the increase in body weight gain of the control treatment. He reported that steers fed on teff straw with wheat bran had higher average daily weight gain than steers fed solely teff straw as a result of higher straw DMI, which in turn resulted from the increased digestibility of teff straw. . 


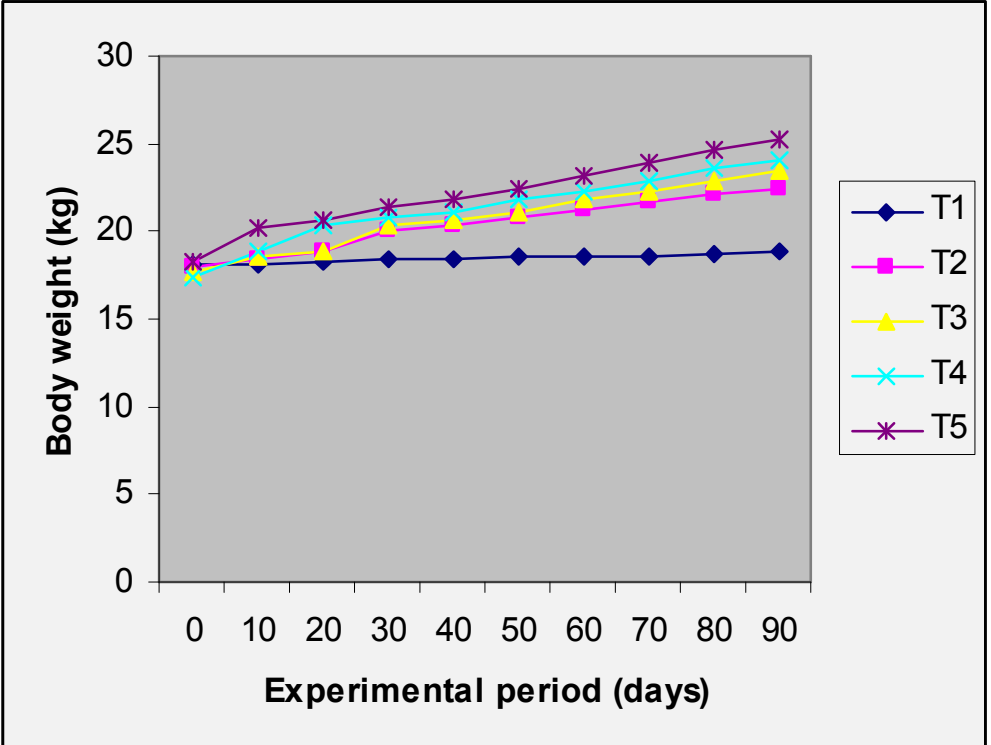

Figure 3 Trends in body weight change of sheep fed on teff straw and supplemented with different levels of sesame seed cake in Tahtay koraro

From the present result, a positive weight gain of sheep was maintained on the control group showed us that wheat bran is very important in improving the nutritive values of poor quality roughages. However, the result was similar to the study of Hadji Panayiotou et al. (1991), who reported, feeding energy concentrates with barley straw cover the maintenance requirement of Awassi sheep. The final live weight gain was significantly $(p<0.05)$ higher for the highest level (T5) sesame seed cake supplemented group as compared to the control treatment. But there was no significant ( $\mathrm{p}>0.05$ ) difference among the supplemented treatments $\mathrm{T} 1, \mathrm{~T} 2, \mathrm{~T} 3$ and $\mathrm{T} 4$, even though there was numerically an increasing trend as the level of sesame seed cake supplementation increased in both cases. This might be due to the inclusion of wheat bran had contributed to the experimental animals to maintain their growth for the control groups.

Table 6: Body weight change, feed conversion ratio and efficiency of sheep fed on teff straw and supplemented with different levels sesame seed cake in Tahtay koraro woreda

\begin{tabular}{|c|c|c|c|c|c|c|c|}
\hline Initial body weight(kg) & $\begin{array}{l}\text { T1 } \\
18.1^{\mathrm{a}}\end{array}$ & $\begin{array}{l}\text { T2 } \\
18.0^{\mathrm{a}}\end{array}$ & $\begin{array}{l}\text { T3 } \\
17.7^{\mathrm{a}}\end{array}$ & $\begin{array}{l}\text { T4 } \\
17.45^{a}\end{array}$ & $\begin{array}{l}\text { T5 } \\
18.3^{\mathrm{a}}\end{array}$ & $\begin{array}{l}\text { SL } \\
\text { ns }\end{array}$ & $\begin{array}{l}\text { SEM } \\
1.172\end{array}$ \\
\hline $\begin{array}{c}\text { Final body weight } \\
\text { (kg) }\end{array}$ & $18.8^{b}$ & $22.5^{\mathrm{ab}}$ & $23.4^{\mathrm{ab}}$ & $24.0^{\mathrm{ab}}$ & $25.3^{\mathrm{a}}$ & $* *$ & 1.131 \\
\hline verage daily live weight gain(g) & $7.8^{\mathrm{c}}$ & $60.0^{b}$ & $63.2^{\mathrm{b}}$ & $72.8^{\mathrm{ab}}$ & $77.8^{\mathrm{a}}$ & $* *$ & 9.658 \\
\hline FCR(g DMI/g LWG) & $29.0^{\mathrm{a}}$ & $15.33^{b}$ & $15.0^{b}$ & $11.0^{b}$ & $10.33^{b}$ & $* *$ & 4.272 \\
\hline FCE (g LWG/g DMI) & $2.47^{b}$ & $6.84^{b}$ & $8.96^{b}$ & $9.54^{b}$ & $14.4^{\mathrm{a}}$ & $* *$ & 2.361 \\
\hline
\end{tabular}

a, ab, Means within the same rows not bearing a common superscript differ significantly; ns = not significant; $\mathrm{SEM}=$ Standard error of mean., $\mathrm{SL}=$ significance level, $\mathrm{FCR}=$ feed conversion ratio $\mathrm{FCE}=$ feed conversion efficiency; $\mathrm{DMI}=$ dry matter intake; $\mathrm{LWG}=$ live weight gain, $\mathrm{ADBWG}=$ average daily body weight gain

Correlation between nutrients intake, digestibility and daily Body weight gain of sheep.

The result of the correlation analysis indicated that dry matter intake was positively $(\mathrm{p}<0.05)$ correlated with DMD (0.59), OMI (0.99), OMD (0.56), CPI (0.84), CPD (0.79) and CFI (0.86) (Table7). The daily body weight gain was also positively $(\mathrm{p}<0.05)$ correlated with DM $(0.53)$, OM $(0.52)$, CP $(0.73)$ intake and digestibility. Similarly, positive but non significant $(\mathrm{p}>0.05)$ correlation was observed between daily body weight gain and $\mathrm{CF}$ (0.18) intake. On the other hand, average daily body weight gain was negatively, but insignificantly $(\mathrm{p}>0.05)$ correlated with ADFI. Similarly, CP intake and digestibility were positively and significantly $(p<0.05)$ correlated with $\mathrm{DM}$ and $\mathrm{OM}$ intake and digestibility. 
Table 7: The correlation between dry matter and nutrients intake, digestibility and daily body weight gain of sheep fed on teff straw and supplemented with different sesame seed cake.

\begin{tabular}{|c|c|c|c|c|c|c|c|c|c|c|c|}
\hline & DMI & DMD & OMI & OMD & CPI & CPD & CFI & CFD & ADFI & ADFD & DBWG \\
\hline DMI & 1 & & & & & & & & & & \\
\hline DMD & $0.59 * *$ & 1 & & & & & & & & & \\
\hline OMI & $0.99 * * *$ & $0.58 * *$ & 1 & & & & & & & & \\
\hline OMD & $0.56 * *$ & $0.99 * * *$ & $0.56^{* *}$ & 1 & & & & & & & \\
\hline CPI & $0.84 * * *$ & $0.61 * *$ & $0.82 * * *$ & $0.63 * *$ & 1 & & & & & & \\
\hline CPD & $0.79 * * *$ & $0.65 * *$ & $0.77 * * *$ & $0.64 * *$ & $0.86^{* * * *}$ & 1 & & & & & \\
\hline CFI & $0.86 * * *$ & $0.35 *$ & $0.87 * * *$ & $0.3 *$ & $0.46^{*}$ & $0.42 *$ & 1 & & & & \\
\hline CFD & $0.33^{*}$ & $0.82 * * *$ & $0.33^{*}$ & $0.82 * * *$ & $0.26^{*}$ & $0.22^{\mathrm{ns}}$ & $0.31 *$ & 1 & & & \\
\hline ADFI & $0.58 * *$ & $0.19^{\mathrm{ns}}$ & $0.6^{* *}$ & $0.12^{\mathrm{ns}}$ & $0.04^{\mathrm{ns}}$ & $0.2^{\mathrm{ns}}$ & $0.85 * * *$ & $0.2^{\mathrm{ns}}$ & 1 & & \\
\hline ADFD & $-0.02^{\text {ns }}$ & $0.06^{\mathrm{ns}}$ & $-0.02^{\mathrm{ns}}$ & $0.07^{\mathrm{ns}}$ & $0.12^{\mathrm{ns}}$ & $-0.06^{\mathrm{ns}}$ & $-0.09^{\mathrm{ns}}$ & $0.19^{\mathrm{ns}}$ & $-0.24^{\mathrm{ns}}$ & 1 & \\
\hline DBWG & $0.53 * *$ & $0.48 *$ & $0.52 * *$ & $0.5^{*}$ & $0.73 * *$ & $0.7 * *$ & $0.18^{\mathrm{ns}}$ & $0.28^{*}$ & $-0.09^{\mathrm{ns}}$ & $0.12^{\mathrm{ns}}$ & 1 \\
\hline
\end{tabular}

$\mathrm{ns}=$ non significant; DBWG = daily body weight gain; DMI= dry matter intake; DMD= dry mater digestibility, $\mathrm{OMI}=$ organic matter intake, $\mathrm{OMD}=$ organic matter digestibility, $\mathrm{CPI}=$ crude protein intake; $\mathrm{CPD}=$ crude protein digestibility; $\mathrm{CFI}=$ crude fiber intake; $\mathrm{CFD}=$ crude fiber digestibility; $\mathrm{ADFI}=$ acid detergent fiber intake; ADFD = acid detergent fiber digestibility;

\section{CHAPTER5: CONCLUSIONS AND RECOMMONDATIONS} Conclusions

The digestibility trial was undertaken after 21days of the adaptation period and the total collection of feces was conducted for seven consecutive days after 3 days of adapting the lambs to the carrying of fecal bags. Daily feed intake was recorded for every day for every lamb against its identification number and their body weight was recorded every 10 days interval. Samples of teff straw offer and refusals, sesame seed cake, wheat bran and the concentrate mixture and feces were chemically analyzed for their nutrient contents.

At the end of the feeding trial, all the experimental animals from each feeding treatment were slaughtered to collect data on carcass parameters.

Teff straw dry matter intake was significantly reduced $(\mathrm{p}<0.05)$ in sesame supplemented group as a result of high level sesame supplementation, which indicated a substitution effect at these levels of supplementation. As the level of sesame supplement increased, the DM and OM intake of teff straw decreased, while the total DM and $\mathrm{OM}$ intake of the lambs increased $(\mathrm{p}<0.05)$.

The apparent digestibility of CP, OM and DM were significantly higher $(\mathrm{p}<0.05)$, for lambs supplemented with higher levels of sesame cake than the control one. Generally the growing lambs in the control group had the lowest digestibility result for all the nutrients except for $\mathrm{CF}$, ADF and ADL digestibility. This result showed that $\mathrm{CF}, \mathrm{ADF}$ and ADL digestibility were neither improved nor depressed by the level of sesame cake supplementation.

There were significantly higher $(\mathrm{p}<0.05)$ feed conversion efficiency in $\mathrm{T} 5$ than the other treatments $(\mathrm{T} 1, \mathrm{~T} 2$, T3 and T4). Even though there was no significant difference among T1, T2, T3 and T4, numerically T1 had the lowest feed conversion efficiency compared to the other treatments. This indicates the control treatment group was utilized their feed less efficiently than the other treatments. Superior daily live weight gain was recorded in lambs supplemented with the highest level of sesame cake as compared to the inferior daily live weight gain in the control treatment. However, a positive average daily body weight gain was observed in the unsupplemented group, indicating animals can survive on wheat bran based feeding.

The average values of slaughter weight and empty body weight were significantly $(\mathrm{p}<0.05)$ higher for the higher supplemented lambs (T3, T4 and T5) than the T2 sesame supplemented and control treatments. This result indicates that lambs consuming the higher level of sesame cake were relatively able to put more lean muscle than the two treatment groups (T1 and T2). Rib-eye area was significantly higher $(\mathrm{p}<0.05)$ for sesame supplemented lambs than the control treatment, but there was no significant difference $(\mathrm{p}>0.05)$ among the sesame supplemented groups. The dressing percentage on slaughter weight base was significantly higher $(\mathrm{p}<0.05)$ in the T3, T4, and T5 level concentrate mixture supplemented treatments than in the T2 sesame cake supplemented and the control treatments. The highest hot carcass weight was recorded with the highest level of sesame cake supplementation (T5), while the lowest hot carcass weight was observed on the control diet (T1). Supplementation of different level of sesame cake had no effect on the weight of lung, trachea, and esophagus, empty gut, omaso-abomasum, large intestine, tongue, and gut content, even though there was numerically an increasing trend as the level of supplementation increased, except for gut content which was higher in the lower level supplemented group next to the control treatment (i.e. T1 $>$ T2 $>$ T3 $>$ T4 $>$ T5). This was associated with higher intake of teff straw dry matter in order to get their nutrient requirement. On the other hand, lambs supplemented with high sesame cake had higher blood weight, larger liver size with gallbladder, heart, and kidneys as compared to the control treatment. The weight of tail, skin, testicle and penis, and the total usable offal components were increased as the level of supplementation increased. 
DM intake was positively and significantly $(\mathrm{p}<0.05)$ correlated with OM intake, CP intake, CF intake, and daily body weight gain. Similarly, Slaughter weight was positively and significantly $(\mathrm{p}<0.05)$ correlated with hot carcass weight, empty body weight, rib-eye area, liver, heart, and kidneys. But slaughter weight was negatively and significantly $(\mathrm{p}<0.05)$ correlated with gut content.

Generally, the present study indicated that supplementation of sheep with different levels of sesame cake had an effect on feed intake, digestibility, and carcass parameters, and the effects were relatively more pronounced on lambs supplemented with the highest level of sesame cake. The partial budget analysis also indicated that the highest level of sesame cake supplemented lambs had returned relatively higher profit margin than the other levels of supplementation. Therefore, from the given levels of supplementation of with teff straw $300 \mathrm{gDM}$ sesame seed cake is biologically more efficient and economically more profitable and thus could be recommended.

\section{Recommendations}

$\checkmark \quad$ In the study area, teff straw is less valued as animal feed to small ruminants by the community as a result, most of the time it is used for large ruminants. But, from the present finding teff straw with wheat bran energy concentrate was able to maintain the nutrient requirement of the animals; therefore, it should be used as small ruminant feed with supplementation.

$\checkmark$ To generate more information, further research should be conducted in supplementation of mixtures of crude protein with energy sources $(>150 \mathrm{~g}$ wheat bran) along with same levels of sesame oil cake based feeding of the same breed sheep to evaluate the animal response, the appropriate level and the economic feasibility of such feeding systems.

$\checkmark$ The effect of supplementation with graded levels of the concentrate mixture used in this study on the carcass quality should be considered.

$\checkmark$ Fattened rams should be sold in a timely fashion that is just before the Ethiopian public holiday (Easter, X-mass, Aid and Ethiopian New Year or Meskel) so that the net profit will be realized.

$\checkmark$ As breed is a prime factor that influences performance, further researches are recommended to characterize the sheep breed locally available in the woreda because they are not yet characterized so far.

\section{Reference}

Akinsoyinu, A.O., U.A. Mba and O.F. Olubajo, 1975. Studies on energy and protein utilization for pregnancy and lactation by the West African Dwarf goats in Nigeria. East African Agric. J. 41: 167-176.

Alemu Yami, (1981). Laboratory evaluation and estimation of nutritive value of some feedstuffs produced in the Alemaya Woreda. An MSc Thesis presented to the school of graduate studies of Alemaya University.pp.81.

Alemu Yami, Zinash Sileshi and Seyoum Bediye, (1989). The potential of crop residues and agro-industrial byproducts in Ethiopian highlands. Pp. 57-64. Proceeding of the third National Livestock Improvement Conference held 24-26 may, 1989. Addis Ababa, Ethiopia.

Alemu Yami, Zinash Sileshi and Seyoum Bediye, (1991). The potential of crop residues and agro-industrial byproducts as animal feed. Pp.57-64. In: IAR proceeding. Third National Livestock Improvement Conference held 24-26 March, 1989, Addis Ababa, Ethiopia. Institute of agricultural research. Addis Ababa.

ARC (Agricultural Research Council), (1980). The nutrient requirement of ruminant's livestock. Common wealth agricultural bureax, slough, England. Pp.351.

AOAC (Association of official Agricultural Chemists), (1990). Official methods of analysis. Association of official Agricultural Chemists, Washington, D.C.pp.1298.

Asnakew Aweke, 2005. Feedlot fattening performance and carcass characteristics of intact male Hararghe highland goats fed different levels of hay to concentrate ratios. An MSc Thesis Presented to the School of Graduate Studies of Alemaya University of Agriculture, Ethiopia. 65p

Banerjee, (2000). A text book of ANIMAL HUSBANDRY Eighth Edition.

Beyene Chichaibelu, C.E. Copper and R.E. McDowell, (1977). laboratory evaluation and estimation of nutritive value of Ethiopia feedstuff and formula feeds. AAASAIV(2):9-24.

Bonsi, M.L.K., A.K. Tuah, P.O. Osuji, V.I. Nsahlai and N.N. Umunna, 1996. The effect of protein supplement sources or supply pattern on the intake, digestibility, rumen kinetics, nitrogen utilization and growth of Ethiopian Menze sheep fed tefff straw. Animal Feed Science and Technology. 64: 11-25.

Central Statistical Office (CSA), (2005). Results of Agricultural Sample Surveys. Government of Ethiopia. Addis Ababa, Ethiopia.

Crabrtree, J.R and L.G. Williams, 1971. The voluntary intake and utilization of roughage concentrate supplement for hay and straw. Anim. Prod.13: 71-82.

Devendra, C., (2001). Small ruminants: imperatives for productivity enhacement, improved livelihoods and rural 
growth-review. Asian-Aust.J.of Anim.Sci.14(10):1481-1496.

Drouillard, J.J., S.T. Klopfetein, A.R. Britton, L.M. Baver, M.S. Gramlich, J.T. Wester and L.C. Ferell, (1991). Growth, body composition and visceral organ mass and metabolism in lambs during and after metabolizable protein or net energy restriction. J.Anim.Sci. 69:3357-3375.

Ensminger, M.E., (2002). Sheep and goat science. $6^{\text {th }}$ (ed.).pp.342-385. international publishers, Inc., Danville, Illinois.

FAO (Food and Agricultural Organization), (1983). Production yearbook, 1982, Vol.36.FAO, Rome.

FAO/ILRI, (1999). (Food and Agriculture Organization and International Livestock Research Institute). Farmers, their animals and the environment. Feed and Nutrition.

Gatenby, R.M.,1991. Sheep. The Tropical Agriculturalist, CTA, Macmilan Educational Ltd. London.154p.

Gatenby, R.M., (2002). Sheep The tropical agriculturalist $2^{\text {nd }}$ (ed.). pp. 1-66. Technical center for Agricultural and Rural Cooperation (ACPEU). The Netherlands.

Getnet berhanu, (1998). Performace of Somali goat supplemeted with different proportion of groundnut cake and wheat bran. An MSc Thesis presented to the Graduate Studies of Alemaya University of Agriculture, Ethiopia. pp.55.

Getnet Berhanu, Alemu Yami and Mekonen Hailemariam, 1999. Performance of lactating Somali does supplemented with different proportions of groundnut cake and wheat bran. pp. 197-211. In: Proceedings of the $7^{\text {th }}$ Annual Conference of Ethiopian Society of Animal Production (ESAP). 26-27 May 1999, Addis Ababa, Ethiopia.

Hadjipanyiotou, M. and P. Morand-Fehr, 1991. Intensive feeding of dairy goats. pp.197-208. In: P. Morand- Fehr ed., Goat nutrition, EAAP Publication No.46, Pudoc, Wageningen, the Ntherlands.

ILRI (International Livestock Research Institute), (1995). Building a global research institute. ILRI. Addis Ababa, Ethiopia

Kirton, A.H., D.P. Fourie and E.K. Jury, 1972. Growth and development of sheep. III. Growth of the carcass and non-carcass component of the South Down and Romney and their cross and some relation ships with composition. J. Agric. Res. 15:214-227.

McDonald, P., R.A. Edwards, J.F.D. Greenhalgh and C.A. Morgan, (2002). Animal nutrition. Pp.471-581. $6^{\text {th }}$ ed. Prentice Hall, London.

mcIntire, J.,D. Bourzat and P-pingali, (1992). Crop/livestock interaction in sub-saharan Africa. World Bank, Washington DC. USA. pp. 103-133.

Naju, B.C., O.P. Kasali, R.G. Scholten, D. Mesfin, (1988). Review of sheep mortality in the Ethiopian highlands, 1982-86. ILCA (Ineternational livestock Research Center for Africa) Addis Ababa, Ethiopia. 31: 19-22.

Njie, M., (1995). Economics assessment of feeding strategies for fattening ram lambs using sesame cake in the Gambia. pp. 192-198. In: agricultural science for biodiversity and sustainability in developing countries. Proceeding of a workshop held 3-7 April 1995, Tune Land boskole, Denmark.

NRC (National Research council), 1981. National Research for Goats. Academy Press, Washington, DC. 84p

Preston, T.R. and R.A. Leng. (1984). Supplementation of diets based on fibrous residues and by-products. pp. 373-413. In: F. Sundstol and E. Owens (eds.). Straw and other fibrous by-products as feeds. Elsevier publishing company.

Ranjhan, S.K., 1997. Animal Nutrition in the Tropics. $4^{\text {th }}$ edn. Vikas publishing house Pvt. Ltd., New Delhi, India. pp.30-57.

Seyoum Bediye and zinash sileshi, (1989). Chemical composition, introdigestibility an energy value of Ethiopian feed stuffs. pp. 307-311. in: proceeding of the Third National Conference of the Ethiopian Society of animal production Addis Ababa, Ethiopia(ESAP), held 27-29 April 1995, Addis Ababa, Ethiopia.

Seyoum Bediye and Zinash Sileshei, (1998). Utilization o tef straw as livestock feed: review.pp173-185. In proceeding of the fifth annual conference of Ethiopia society of animal production. ESAP (Ethiopia society of animal production) held14-15 may 19198, Addis Ababa, Ethiopia

Smith, T., (1978). The utilization of poor quality roughage by yearling heifers. PhD Thesis, University of Reading, U.K. 198P.

Tesfaye Woldemichael, P.O. Osuji and Asfaw Yimegnuhal, (2001). Effect of wheat bran supplementation at graded levels on changes in physical body composition in tef straw (eragrostis tef) fed zebu (Bos undicus) oxen of Ethiopian highlands.pp. 99-109. proceeding of $9^{\text {th }}$ Annual Conference of the Ethiopian society of animal production (ESAP) held 30-31 August, 2001, Addis Ababa, Ethiopia.

Tesfay Hagos, 2007. Supplementation of Afar rams with graded levels of mixtures of protein and energy sources: effects on feed intake, digestibility, live weight and carcass parameters.An MSc Thesis Presented to the School of Graduate Studies of Alemaya University of Agriculture, Ethiopia.

Trach, N.X., 2004. An evaluation of adaptability of alkali treatment of rice straw as feed for growing beef cattle under small holder' circumstances. Livestock Res. Rural Dev. 16(7).

Van soest, P.J., (1988). Effect of environment and quality of fiber on the nutritive value of crop residue. In: 
Van soest, P.J., (1994). Nutritional ecology of the ruminant. Cornell university press, Ithaca and London .pp.476.

Zemicael Gereslassie, (2007). Supplementation of sesame seed (Sesame indicum) cake, wheat bran and their mixtures on feed intake, digestibility, live weight changes and carcass characteristics of Arado sheep fed a basal diet of teff straw. An MSc Thesis Presented to the School of Graduate Studies of Alemaya University of Agriculture, Ethiopia. 57p.

Zinash Sileshi and Seyoum Bediye, (1991). Utilization of feed resource and feeding system in the central zone of Ethiopia.pp.129-132. in; IAR proceeding o f third national livestock improvement conference held in Addis Ababa, 24-26 may 1989. IAR (Iinstitute of agricultural research), Addis Ababa, Ethiopia. 